\title{
ANALISIS PENGARUH KUALITAS PRODUK, KUALITAS LAYANAN DAN PERSEPSI HARGA TERHADAP KEPUASAN KONSUMEN AIR MINUM DALAM KEMASAN
}

\author{
Hermansyah \\ Fakultas Ilmu Sosial dan Ilmu Politik Universitas Kapuas \\ Email: hermansyah.unkas90@gmail.com
}

\begin{abstract}
Abstrak: Sementara tujuan yang ingin dicapai dari penelitian adalah untuk mengetahui dan menganalisis: Pengaruh kualitas produk terhadap kepuasan konsumen; Pengaruh kualitas layanan terhadap kepuasan konsumen. Pengaruh persepsi harga terhadap kepuasan konsumen. Pengaruh pengaruh kualitas produk, kualitas layanan, persepsi harga terhadap kepuasan konsumen.

Penelitian ini akan digunakan rancangan penelitian exsplanatory yang menyoroti hubungan antar variabel independen dengan variabel dependen dan menguji hipotesis yang telah dirumuskan sebelumnya. Variabel Penelitian terdiri dari 1) Variabel Terikat (Dependent) . Variabel Terikat yang digunakan dalam penelitian ini adalah Kepuasan Konsumen (Y). Variabel Bebas (Independent) yang digunakan dalam penelitian ini adalah: Kualitas Produk $\left(\mathrm{X}_{1}\right)$, Kualitas Layanan $\left(\mathrm{X}_{2}\right)$, Persepsi Harga $\left(\mathrm{X}_{3}\right)$. Sampel penelitian berjumlah 45 responden. Sementara untuk pembuktian hipotesis dilakukan dengan uji pengaruh di gunakan uji t, uji ANOVA atau $\mathrm{F}$ test dan Koefisien Determinasi $\mathrm{R}^{2}$

Hasil penelitian: pertama; Terdapat pengaruh positif dan signifikan kualitas produk terhadap kepuasan konsumen hal tersebut dibuktikan dengan Uji t adalah sebagai berikut dimana Nilai thitung pada variabel Kualitas Produk $\left(\mathrm{X}_{1}\right)$ adalah sebesar 2,606 > t tabel 1,989 maka Ha diterima. Kedua; Terdapat pengaruh positif dan signifikan kualitas layanan terhadap kepuasan konsumen hal tersebut dibuktikan dengan Uji t hitung pada variabel Kualitas Layanan $\left(\mathrm{X}_{2}\right)$ adalah sebesar 3,199 $>\mathrm{t}$ tabel 1,989, maka Ha diterima. Ketiga; Tidak Terdapat pengaruh positif dan signifikan persepsi harga terhadap kepuasan konsumen hal tersebut dibuktikan dengan Uji t hitung pada variabel Persepsi Harga $\left(\mathrm{X}_{3}\right)$ adalah sebesar 1,563 dengan tingkat signifikansi 0,122 . Karena thitung $1,563<$ ttabel 1,989 dengan tingkat signifikansi $0,122>0,05$ maka Ho diterima dan Ha ditolak. Keempat; Terdapat pengaruh positif dan signifikan pengaruh kualitas produk, kualitas layanan, persepsi harga terhadap kepuasan konsumen ini dibuktikan uji ANOVA atau F test, maka dapat diperoleh $\mathrm{F}$ hitung sebesar 8,653 dengan tingkat signifikansi 0,000. Oleh karena probabilitas jauh lebih kecil daripada 0,05 (0,000 lebih kecil dari 0,05). Selanjutnya Adjusted $R$ Square adalah 0,243 . Hal ini berarti hanya 24,3 persen variasi kepuasan pelanggan $(Y)$ yang dapat dijelaskan oleh variabel-variabel independen yaitu kualitas produk, persepsi kualitas layanan, dan persepsi harga. Sedangkan sisanya $(100 \%-24,3 \%=75,7 \%)$ dijelaskan oleh sebab-sebab lainnya di luar model yang tidak diteliti dalam penelitian ini. Dari hasil penelitian, peneliti memberikan rekomendasi pertama; Sebaiknya Air Minum Dalam Kemasan CV. Sentosa Abadi di Kabupaten Sekadau untuk meningkatkan kepuasan konsumen meningkatkan kualitas produk dengan berbagai tampilan yang menarik. Kedua; Sebaiknya Air Minum Dalam Kemasan CV. Sentosa Abadi di Kabupaten Sekadau untuk meningkatkan kepuasan konsumen meningkatkan Persepsi Kualitas Layanan dengan cepat dan reponsif. Ketiga; Sebaiknya Air Minum Dalam Kemasan CV. Sentosa Abadi di Kabupaten Sekadau untuk meningkatkan kepuasan konsumen menuntukan harga jual terendah yang dapat terjangkau oleh konsumen dan masih menguntungkan pihak perusahaan.
\end{abstract}

Kata Kunci: Kualitas Produk, Kualitas Layanan, Persepsi Harga, Kepuasan Konsumen

Perusahaan adalah suatu lembaga yang diorganisir dan dijalankan untuk menyediakan barang dan jasa agar dapat melayani permintaan konsumen akan kebutuhan mereka. Perusahaan 
akan sukses apabila mengutamakan kepuasan bagi para konsumennya. Kepuasan bagi konsumen akan datang dengan sendirinya bila produk/jasa yang dijual perusahaan sesuai atau melampaui apa yang diinginkan oleh konsumen. Apabila perusahaan melakukan suatu kesalahan yang merusak citranya maka hal ini akan menimbulkan akibat buruk bagi perusahaan sebab konsumen akan meninggalkan perusahaan dan menjadi konsumen dari perusahaan pesaingnya. Kualitas produk, kualitas layanan dan persepsi harga berpengaruh terhadap perilaku konsumen yaitu melalui kepuasan konsumen. Melalui kepuasan itu konsumen akan melakukan pembelian barang dan jasa atau yang pada akhirnya akan merekomendasikan hal itu kepada orang lain.

Agar perusahaan dapat sukses dalam persaingan adalah berusaha mencapai tujuan untuk menciptakan dan mempertahankan konsumen. Oleh karena itu setiap perusahaan selalu berupaya menghasilkan barang dan jasa yang sesuasi dengan keinginan konsumen atau konsumen dengan harga yang pantas dan pelayanan yang prima. Dengan demikian, setiap perusahaan harus mampu memahami perilaku konsumen pada pasar sasarannya, karena kelangsungan hidup perusahaan tersebut sebagai organisasi yang berusaha memenuhi kebutuhan dan keinginan para konsumen sangat tergantung pada perilaku konsumen. Perilaku konsumen sendiri merupakan tindakan-tindakan individu yang secara langsung terlibat dalam usaha memperoleh, menggunakan dan menentukan produk dan jasa, termasuk proses pengambilan keputusan dalam melakukan pembelian barang dan jasa. Pemahaman terhadap perilaku konsumen bukanlah suatu pekerjaan yang mudah, tetapi cukup sulit dan kompleks untuk pahami oleh pihak perusahaan atau para produsen barang atau jasa. Jika perusahaan berhasil dapat memahami keinginan konsumen atau konsumen, maka perusahaan yang bersangkutan akan dapat meraih keuntungan yang jauh lebih besar dari pada pesaingnya, karena dengan dipahaminya perilaku konsumen, perusahaan dapat memberikan kepuasan secara lebih baik kepada konsumennya.

Dalam pemasaran ada konsep kepuasan konsumen yang digunakan untuk menilai seorang konsumen itu merasa puas atau tidak menurutb Tjiptono (1996) dapat dibedakan sebagai berikut: a) Positive Disconfirmation, b) Simple Disconfirmation; c) Negative Disconfirmation. Kelangsungan hidup sebuah perusahaan sangat tergantung pada kepuasan para konsumennya dan kemampuan menghasilkan laba. Sebuah perusahaan yang mampu memuaskan kebutuhan konsumennya, akan tetapi tidak mampu menghasilkan laba, tidak mungkin akan tetap eksis dan berkembang. Kepuasan konsumen dan laba harus dicapai secara simultan. Pendekatan berdasarkan kepentingan konsumen (customer oriented) sebaiknya dilakukan secara lebih sistematis dan efektif.

CV. Sentosa Abadi sebagai salah satu perusahaan yang bergerak di bidang produksi Air Minum Dalam Kemasan yang mempunyai memiliki karyawan sebanyak 21 orang termasuk Direkturnya. Penenpatan karyawan 16 untuk kegiatan produksi dan 7 orang bangian kantor nya. CV. Sentosa Abadi memproduksi Air Minum Dalam Kemasan dengan bentuk kemasan berupa Gallon, Botol dan gelas sebagaimana terlihat pada tabel berikut ini.

Tabel. 1. Produksi Air Minum Dalam Kemasan CV. Sentosa Abadi Berdasarkan Jenis Kemasan Perhari

\begin{tabular}{|c|c|c|}
\hline No & Jenis Kemasan & Volume Bersih \\
\hline 1 & Gallon & 19 Liter \\
\hline 2 & Botol & $600 \mathrm{ml}$ \\
\hline 3 & Gelas & $240 \mathrm{ml}$ \\
\hline
\end{tabular}


Sumber: CV. Sentosa Abadi Kabupaten Sekadau, 2014

CV. Sentosa Abadi memasarkan hasil produksi dengan daerah pemasaran meliputi 3 kabupaten; yaitu Kabupaten Sekadau, Kabupaten Sanggau dan Kabupaten Sintang. Perusahaan ini juga mendapat saingan dari perusahaan sejenis sehingga merasa perlu terus meningkatkan produktivitas tenaga kerja agar biaya produksi menjadi lebih rendah dan dapat bersaing dalam harga jual hasil produksi. Sejalan dengan uraian di atas, peneliti merasa tertarik untuk melakukan penelitian dengan judul: “ Analisis Pengaruh Kualitas Produk, Kualitas Layanan Dan Persepsi Harga Terhadap Kepuasan Konsumen Air Minum Dalam Kemasan Pada CV. Sentosa Abadi Kabupaten Sekadau"

Sejalan dengan uraian di atas menunjukkan pentingnya penelitian yang secara komprehensif mengintegrasikan faktorfaktor yang ditengarai mempengaruhi kepuasan konsumen. Dengan demikian pertanyaan dalam penelitian ini adalah : (1). Apakah ada pengaruh kualitas produk terhadap kepuasan konsumen? (2). Apakah ada pengaruh kualitas layanan terhadap kepuasan konsumen? (3). Apakah ada pengaruh persepsi harga terhadap kepuasan konsumen? (4). Apakah ada pengaruh kualitas produk, kualitas layanan, persepsi harga terhadap kepuasan konsumen? Sementara tujuan yang ingin dicapai dari penelitian ini adalah: (1). Menganalisis pengaruh kualitas produk terhadap kepuasan konsumen. (2). Menganalisis pengaruh kualitas layanan terhadap kepuasan konsumen. (3). Menganalisis pengaruh persepsi harga terhadap kepuasan konsumen. (4). Menganalisis pengaruh pengaruh kualitas produk, kualitas layanan, persepsi harga terhadap kepuasan konsumen.

Menurut American Society for Quality Control (dalam Lupiyoadi, 2001), kualitas adalah keseluruhan ciri-ciri dan karakteristik-karakteristik dari suatu barang atau jasa, dalam hal kemampuan untuk memenuhi kebutuhankebutuhan yang telah ditentukan atau bersifat laten. Garvin (dalam Tjiptono, 2005), indikator yang digunakan untuk mengukur kualitas produk, yaitu : 1. Fitur, 2. Reliabilitas, 3. Kesesuaian dengan spesifikasi, 4. Daya tahan, 5. Keindahan. Lupiyoadi (2001), menjelaskan bahwa pada dasarnya terdapat tiga orientasi kualitas yang seharusnya konsisten satu sama lain, yaitu: Persepsi konsumen, Produk atau jasa, Proses. Untuk yang berbentuk barang, ketiga orientasi ini hampir selalu dapat dibedakan dengan jelas. Tetapi untuk yang berupa jasa, produk, dan proses tidak dapat dibedakan dengan jelas bahkan produknya adalah proses itu sendiri.

Kotler (1992), produk didefinisikan sebagai sesuatu yang dapat ditawarkan ke dalam pasar untuk dapat memuaskan keinginan atau kebutuhan. Menurut Parasuraman, et.al (1988), perceived quality adalah penilaian konsumen akan entitas kesempurnaan atau superioritas. Parasuraman, et.al (1991), menyatakan bahwa persepsi secara tunggal didefinisikan sebagai suatu evaluasi atau penilaian keseluruhan kualitas barang atau jasa itu sendiri.

Parasuraman, et.al (1991) dan Gronroos (1994), menyatakan bahwa kualitas layanan adalah merupakan evaluasi keseluruhan darifungsi jasa yang diterima secara aktual oleh konsumen (kualitas teknis), dan bagaimana cara layanan tersebut disampaikan (kualitas fungsional). Apabila layanan yang diterima dan dirasakan sesuai dengan harapan konsumen maka kualitas layanan tersebut dianggap sebagai kualitas yang baik, dan sebaliknya apabila kualitas layanan yang diterima dan dirasakan tidak sesuai dengan yang diharapkan konsumen maka kualitas layanan tersebut dipersepsikan buruk. Baik dan buruknya kualitas layanan dilihat dari sudut pandang konsumen, bukan pada penyedia jasa. Parasuraman, et.al (1998), menjelaskan bahwa terdapat lima indicator yang digunakan untuk mengukur kualitas layanan yaitu : 1. Tangibles (bukti fisik), adalah kemampuan suatu perusahaan dalam menunjukkan eksistensinya kepada pihak 
eksternal. 2. Reliability (kehandalan), adalah kemampuan perusahaan untuk memberikan pelayanan sesuai yang dijanjikan secara akurat dan terpercaya. 3. Responsiveness (ketanggapan), adalah suatu kemauan untuk membantu dan memberikan pelayanan yang cepat dan tepat kepada konsumen dengan penyampaian informasi yang jelas. 4. Assurance (jaminan dan kepastian), adalah pengetahuan, kesopansantunan, dan kemampuan para karyawan perusahaan untuk menumbuhkan rasa percaya para konsumen kepada perusahaan. 5.Empathy (empati), adalah memberikan perhatian yang tulus dan bersifat individual atau pribadi yang diberikan kepada para konsumen dengan berupaya memahami keinginan konsumen.

Parasuraman, Zeithami dan Berry (1985), menyatakan ada tiga karakteristik jasa dalam memahami konsep kualitas jasa secara menyeluruh antara lain sebagai berikut: 1 . Intangibility (tidak berwujud). Wujud jasa merupakan kinerja dari suatu objek, maka ketepatan dan keseragaman spesifikasi dalam pabrikasi sering tidak terwujud dalam satu kesatuan. Umumnya jasa tidak dapat dihitung, diukur, diraba dan dibuktikan dalam peningkatannya. 2. Inseparability (tidak dapat dipisahkan). Proses yang terjadi antar produksi dan konsumsi jasa tidak bisa dipisahkan. Umumnya barang diproduksi pada waktu bersamaan dan apabila dikehendaki oleh seseorang untuk diserahkan kepada pihak lainnya maka dia akan tetap merupakan bagian dari pelayanan tersebut. Karena konsumen juga ada pada saat barang diberikan maka hubungan langsung antara perusahaan dengan konsumen merupakan ciri khusus dari pemasaran jasa. 3 . Variability (bervariasi). Pelayanan senantiasa mengalami perubahan tergantung dari siapa penyedia barang, penerima barang, dan kondisi tersebut diberikan. Konsep terdahulu menganjurkan sejumlah atribut secara umum yang digunakan konsumen untuk menjamin kualitas jasa.
Persepsi harga adalah kecenderungan konsumen untuk menggunakan harga dalam memberi penilaian tentang kualitas produk. Harga menurut Stanton (2004) adalah sejumlah uang (kemungkinan ditambah barang) yang ditentukan untuk memperoleh beberapa kombinasi sebuah produk dan konsumen yang menyertai. Menurut Husein (2002), harga adalah sejumlah nilai yang ditukarkan konsumen dengan manfaat dari memiliki atau menggunakan produk barang atau jasa yang nilainya ditetapkan oleh pembeli dan penjual melalui tawar-menawar atau ditetapkan oleh penjual untuk suatu harga yang sama terhadap seorang pembeli. Swastha (2000), mendefinisikan harga adalah sejumlah uang yang dibutuhkan untuk mendapatkan sejumlah barang dan pelayanan. Sedangkan Kotler dan Gary Amstrong (1997), mendefinisikan harga sebagai sejumlah uang yang dibebankan untuk sebuah produk atau jasa. Perusahaan dalam menetapkan suatu harga pada produk mempunyai beberapa tujuan. Menurut Swastha (2000), dibagi menjadi empat, yaitu : 1 . Mendapatkan laba yang maksimal. 2. Mendapatkan pengembalian investasi yang ditargetkan atau pengembalian penjualan bersih. 3. Mencegah atau mengurangi persaingan. 4. Mempertahankan atau memperbaiki market share.

Kepuasan dan ketidakpuasan konsumen adalah sebuah fungsi dari meningkatnya diskonfirmasi atas perbedaan antara harapan yang lampau dengan kinerja objek saat ini. Kepuasan adalah merupakan proses evaluasi yang dilakukan konsumen dimana konsumen bertindak dengan membandingkan antara performance actual dan performance expectation. Bolton dan Drew (1991), menyatakan bahwa kepuasan atau ketidakpuasan konsumen terhadap jasa yang ditawarkan pada saat itu tergantung pada persepsi kinerja yang ada dan persepsi dari kesenjangan antara harapan dan kenyataan. Zeithaml dan Bitner (1996), kepuasan konsumen merupakan 
evaluasi spesifik terhadap keseluruhan pelayanan yang diberikan, dimana pengukuran atau respon konsumen dilakukan secara langsung atas pelayanan yang telah diberikan pemberi jasa, sehingga kepuasan konsumen hanya dapat dinilai berdasarkan pengalaman yang pernah dialami saat proses pemberian pelayanan. Tse dan Wilton (1988), mendefinisikan kepuasan atau ketidakpuasan konsumen sebagai respon konsumen terhadap evaluasi ketidaksesuaian (disconfirmation) dengan dipersepsikan antara harapan awal sebelum pembelian (atau norma kinerja lainnya) dan kinerja aktual produk yang dirasakan setelah pemakaiannya. Kotler (2000), mendefinisikan kepuasan adalah tingkat perasaan seseorang baik senang maupun kecewa setelah membandingkan kinerja atau hasil yang ia rasakan dibandingkan dengan harapannya. Wilkie (1990), mendefinisikan kepuasan konsumen sebagai tanggapan emosional pada evaluasi terhadap pengalaman konsumsi suatu produk atau jasa. Oliver (1997), kepuasan konsumen dirumuskan sebagai evaluasi purnabeli, dimana persepsi terhadap kinerja alternatif produk atau jasa yang dipilih memenuhi atau melebihi harapan sebelum pembelian.

Tjiptono (1996), kepuasan konsumen adalah kinerja yang dirasakan adalah persepsi konsumen terhadap apa yang ia terima setelah mengkonsumsi produk yang dibeli. Ada beberapa metode yang bisa dipergunakan setiap perusahaan untuk mengukur kepuasan konsumen (Kotler, 2002), yaitu : 1. Sistem Keluhan dan Saran. Setiap organisasi yang berorientasi pada konsumen (Costumer Oriented), perlu menyediakan kesempatan dan akses yang mudah serta nyaman bagi para konsumennya guna menyampaikan saran, kritik, pendapat, dan keluhan mereka. 2. Pembeli Bayangan. Yaitu mempekerjakan beberapa orang ghost shopper berperan atau berpura-pura sebagai konsumen potensial produk perusahaan kemudian menilai cara perusahaan melayani permintaan spesifik konsumen, menjawab pertanyaan konsumen, dan menangani setiap keluhan. 3. Analisis Konsumen yang Beralih.
Sedapat mungkin perusahaan seharusnya menghubungi para konsumen yang telah beralih ke perusahaan lain agar dapat memahami mengapa hal itu terjadi, dan supaya dapat mengambil kebijakan perbaikan atau penyempurnaan selanjutnya. 4. Survei Kepuasan Konsumen. Melalui survei, perusahaan akan memperoleh tanggapan secara langsung dari konsumen, dan juga memberikan kesan positif bahwa perusahaan menaruh perhatian terhadap konsumennya.

Ada beberapa strategi yang dapat dipadukan untuk meraih dan meningkatkan kepuasan konsumen, antara lain : 1.Strategi Pemasaran berupa Relationship Marketing (Mc. Kenna, 1991) Yaitu strategi dimana transaksi pertukaran antara pembeli dan penjual berkelanjutan tidak berakhir setelah penjualan selesai. 2. Strategi Superior Customer Service (Schnaar, 1991) Yaitu menawarkan pelayanan yang lebih baik pada pesaing. 3. Strategi penanganan keluhan yang efisien (Schnaar, 1991) Yaitu penanganan keluhan dengan memberikan peluang untuk mengubah seorang konsumen yang tidak puas menjadi konsumen yang puas. 4 .Strategi peningkatan kinerja perusahaan. Meliputi berbagai upaya seperti : melakukan pemantauan atau pengukuran kepuasan konsumen secara berkesinambungan, memberikan pendidikan dan pelatihan menyangkut komunikasi, salesmanship, dan public relation kepada pihak manajemen dan karyawan, serta memberikan empowerment yang lebih besar kepada karyawan dalam melaksanakan tugasnya. 5. $Q u$ a $l i t y$ Function Deployment Yaitu praktik untuk merancang suatu proses sebagai tanggapan terhadap kebutuhan konsumen. Mowen (1995), menjelaskan bahwa terdapat tiga indikator yang dapat digunakan untuk mengukur kepuasan konsumen, yaitu: 1. Attributes Related to Product (atribut - atribut yang berhubungan dengan produk). Terdiri dari: Kemampuan produk dan konsistensinya yakni kemampuan dari produk sesuai dengan yang dijanjikan oleh perusahaan; 2. Attributes Related to Service (atribut-atribut yang berhubungan dengan pelayanan). Terdiri dari: 
Garansi produk yakni garansi yang diberikan sesuai dengan pelayanan purna jual yang telah dijanjikan; 3. Attributes Related to Purchase (atribut - atribut yang berhubungan dengan penjualan). Terdiri dari: Reputasi perusahaan yakni reputasi yang dimiliki oleh perusahaan.

\section{METODE PENELITIAN}

Secara garis besar dalam penelitian ini akan digunakan rancangan (design) penelitian exsplanatory (penjelasan), yang menyoroti hubungan antar variabel independen dengan variabel dependen dan menguji hipotesis yang telah dirumuskan sebelumnya. Variabel Penelitian terdiri dari 1) Variabel Terikat (Dependent)Variabel Terikat (Dependent) yaitu variabel yang tidak bebas atau variable yang tergantung dengan variabel lainnya (Arikunto, 2002). Variabel Terikat yang digunakan dalam penelitian ini adalah Kepuasan Konsumen (Y). Variabel Bebas (Independent) Variabel Bebas (Independent) yaitu variabel yang mempengaruhi atau variabel penyebab (Arikunto, 2002). Variabel Bebas yang digunakan dalam penelitian ini adalah: Kualitas Produk (X1), Kualitas Layanan (X2), Persepsi Harga (X3).

Populasi adalah sekelompok objek yang menjadi sasaran penelitian (Bungin, 2005) Sehingga populasi dalam penelitian ini adalah seluruh konsumen Air Minum Dalam Kemasan CV. Sentosa Abadi Kabupaten Sekadau tahun 2013 berjumlah 493. Dalam penelitian ini teknik sampling yang digunakan adalah "purposive sampling", yaitu pemilihan sample dengan kriteria tertentu (Arikunto, 2000).

Ukuran sampelnya, menurut Umar (2005:146) dapat digunakan teknik Slovin, dengan rumus sebagai berikut:

$$
n=\frac{N}{1+N e^{2}}
$$

Dimana:

$$
\begin{aligned}
& \mathrm{n}=\text { Ukuran Sampel } \\
& \mathrm{N}=\text { Ukuran Populasi }
\end{aligned}
$$

$\mathrm{e}=$ Persen kelonggaran ketidak teliti karena kesalahan pengambilan sampel dalam penelitian ini diambil

$\mathrm{e}=0.1(10 \%)$

$n=\frac{N}{1+N e^{2}}$

$$
\begin{aligned}
& \mathrm{n}=\frac{493}{1+\left(493 \times 0,1^{2}\right)} \\
& \mathrm{n} \quad=83,14 \text { dibulatkan keatas menjadi } 85
\end{aligned}
$$
orang responden.

Teknik pengumpulan data yang penulis gunakan untuk mendapatkan data rresponden, maka penulis menggunakan kuesioner sebagai instrumen pengumpulan datanya. Kuisioner akan disebarkan kepada responden disusun dengan menggunakan skala Likert. Menurut Sugiyono (2008) "skala Likert digunakan untuk mengukur sikap, pendapat, dan persepsi seseorang atau sekelompok orang tentang fenomena sosial".

Dengan skala Likert, maka variabel yang akan diukur dijabarkan menjadi indikator variabel. Kemudian indikator tersebut dijadikan sebagai titik tolak untuk menyusun item-item instrumen yang dapat berupa pernyataan atau pertanyaan. Jawaban setiap item istrumen yang menggunakan skala Likert mempunyai gradasi dari sangat positif sampai sangat negatif, yang dapat berupa kata-kata antara lain:

Tabel 2 Skor Atas Jawaban Kuesioner

\begin{tabular}{|c|l|c|}
\hline No. & \multicolumn{1}{|c|}{ Jenis Jawaban } & Skor \\
\hline 1 & Sangat setuju & 5 \\
\hline 2 & Setuju & 4 \\
\hline 3 & Ragu-ragu & 3 \\
\hline 4 & Tidak setuju & 2 \\
\hline 5 & Sangat tidak setuju & 1 \\
\hline
\end{tabular}

Sumber: Sugiyono, 2008

Cara mengukur validitas dengan melakukan korelasi antar skor butir pertanyaan dengan total skor variabel. Jika r hitung $>$ r tabel dan nilai positif, 
maka pertanyaan atau indikator dinyatakan valid, Ghozali, )2006). Cara mengukur validitas kuesioner dilakukan dengan rumus Teknik Korelasi Produk Moment.

$$
r=\frac{N(\Sigma x y)-(\Sigma x . \Sigma y)}{\left[N \Sigma x^{2}-(\Sigma x)^{2}\right]\left[N \Sigma y^{2}-(\Sigma y)^{2}\right]}
$$

Dimana :

$\mathrm{r}=$ koefisien korelasi

$\mathrm{x}=$ skor pertanyaan

$\mathrm{y}=$ skor total

$\mathrm{N}=$ jumlah responden

$\Sigma=$ total

Menurut Ghozali (2006) Uji Reliabilitas adalah alat untuk mengukur suatu kuesioner yang merupakan indikator dari variabel suatu kuesioner. Dinyatakan reliable/handal jika jawaban seseorang terhadap pernyataan adalah konsisten atau stabil dari waktu ke waktu. Uji Reliabilitas dilakukan dengan bantuan SPSSfor windows, yang memberikan fasilitas untuk mengukur reliabilitas dengan Uji Statistik Cronbach Alpha ( $\alpha$ ). Suatu variabel dikatakan reliabel jika memberikan nilai Cronbach Alpha $>0,60$.

Rumus Cronbach Alpha menurut Arikunto (2002)

$$
\mathrm{a}=\frac{\mathrm{kr}}{1+(\mathrm{k}-1) \mathrm{r}}
$$

Dimana:

$\mathrm{a}=$ koefisien reliabilitas

$\mathrm{r}=$ mean korelasi item

$\mathrm{k}=$ jumlah variabel

$1=$ bilangan konstan

Analisis regresi linear berganda digunakan untuk mengetahui hubungan sebab akibat dengan menentukan nilai Y (sebagai variabel dependen) dan untuk menaksir nilai-nilai yang berhubungan dengan X (sebagai variabel independen), dengan menggunakan rumus statistik atau model matematis
$\mathrm{Y}=\mathrm{b} 0+\mathrm{b} 1 . \mathrm{X} 1+\mathrm{b} 2 . \mathrm{X} 2+\mathrm{b} 3 . \mathrm{X} 3+\mathrm{e}$

Keterangan :

$\mathrm{Y} \quad=$ Kepuasan pelanggan

$\mathrm{X} 1=$ Kualitas Produk

X2 = Kualitas Layanan

$\mathrm{X} 3=$ Persepsi harga

b123 = Koefisien regresi yang hendak diteliti

e $=$ eror

Uji Statistik t pada dasarnya menunjukkan seberapa jauh pengaruh satu variabel independen secara individual dalam menerangkan variasi variabel dependen (Ghozali, 2006). Langkah langkah pengujian adalah sebagai berikut :

a) Menentukan Formulasi Hipotesis

1. Ho : b1 : b2 : b3 =0. Artinya, variabel independen bukan merupakan penjelas yang signifikan terhadap variabel dependen.

2. Ha : b1 : b2 : b3 ${ }^{1} 0$. Artinya, variabel independen merupakan penjelas yang signifikan terhadap variabel dependen.

b) Menentukan Derajat Kepercayaan $5 \%$ $(\mathrm{a}=0,05)$ dari thitung dan ttabel. Dengan jumlah sampel 85 dan menggunakan uji dua sisi didapat ttabel sebesar 1,989. Bila thitung $>$ ttabel maka Ho ditolak dan $\mathrm{Ha}$ diterima. Bila thitung $<$ ttabel maka Ho diterima dan Ha ditolak.

c) Membuat Kesimpulan

1. Bila thitung $>$ ttabel maka Ho ditolak dan Ha diterima, menyatakan bahwa variabel independen secara individual mempengaruhi variabel dependen.

2. Bila thitung $<$ ttabel maka Ho diterima dan Ha ditolak, menyatakan bahwa variabel independen secara individual tidak mempengaruhi variabel dependen.

Uji statistik F pada dasarnya menunjukkan apakah semua variabel independent yang dimasukkan dalam model mempunyai pengaruh secara simultan atau bersama-sama terhadap variabel dependen (Ghozali, 2006 : 84). Variabel independen yaitu kualitas produk (X1), persepsi 
kualitas layanan (X2), dan persepsi harga (X3) yang dimaksukkan dalam model mempunyai pengaruh secara simultan atau bersama-sama terhadap variabel dependen yaitu kepuasan pelanggan (Y) dalam menggunakan produk Air Minum Dalam Kemasan Pada CV. Sentosa Abadi Kabupaten Sekadau

Langkah - langkah pengujian adalah sebagai berikut :

a) Menentukan Formulasi Hipotesis

1. Ho $: \mathrm{b} 1=\mathrm{b} 2=\mathrm{b} 3=\ldots \ldots \ldots \ldots . . .=\mathrm{bk}=0$.

Artinya, apakah semua variabel independen bukan merupakan penjelas yang signifikan terhadap variabel dependen.

2. Ha : b1 ${ }^{1}$ b2 ${ }^{1}$ b3 ${ }^{1}$ ${ }^{1} \mathrm{bk}^{1} 0$. Artinya, semua variabel independent secara simultan merupakan penjelas yang signifikan terhadap variabel dependen.

b) Menentukan Derajat Kepercayaan 5\% (a $=0,05)$ dari Fhitung dan Ftabel. Dengan jumlah sampel 85 dan menggunakan tiga variabel independen didapat Ftabel sebesar 2,71. Bila Fhitung > 2,71 maka Ho ditolak dan Ha diterima, yang menyatakan bahwa semua variabel independen secara serentak dan signifikan mempengaruhi variabel dependen. Bila Fhitung < 2,71 maka Ho diterima dan Ha ditolak, yang menyatakan bahwa semua variabel independen secara serentak dan signifikan tidak mempengaruhi variabel dependen.

c) Membuat Kesimpulan

1. Bila Fhitung $>$ Ftabel maka Ho ditolak dan Ha diterima.

2. Bila Fhitung $<$ Ftabel maka Ho diterima dan Ha ditolak.

HASIL PENELITIAN DAN PEMBAHASAN

Hasil Uji Validitas

\begin{tabular}{|l|c|c|c|c|c|}
\hline Variabel & Kode Item & r hitung & r tabel & Sig. & Kriteria \\
Kualitas Produk (X1) & Q4 & 0,703 & 0,215 & 0 & Valid \\
& Q5 & 0,638 & 0,215 & 0 & Valid \\
Q6 & 0,702 & 0,215 & 0 & Valid \\
& Q7 & 0,613 & 0,215 & 0 & Valid \\
Q8 & 0,734 & 0,215 & 0 & Valid \\
Persepsi Kualitas Layanan (X2) & Q9 & 0,699 & 0,215 & 0 & Valid \\
& Q10 & 0,738 & 0,215 & 0 & Valid \\
Q11 & 0,758 & 0,215 & 0 & Valid \\
Q12 & 0,511 & 0,215 & 0 & Valid \\
& Q13 & 0,576 & 0,215 & 0 & Valid \\
& Q14 & 0,796 & 0,215 & 0 & Valid \\
Kepuasan Konsumen (Y) & Q15 & 0,812 & 0,215 & 0 & Valid \\
& Q16 & 0,737 & 0,215 & 0 & Valid \\
& Q1 & 0,754 & 0,215 & 0 & Valid \\
& Q2 & 0,738 & 0,215 & 0 & Valid \\
& Q3 & 0,73 & 0,215 & 0 & Valid \\
\hline
\end{tabular}

Sumber : Data primer diolah dengan SPSS For Windows 
Dari di atas, terlihat hasil Uji Validitas menunjukkan bahwa nilai rhitung dari masingmasing variabel lebih besar dari rtabel sebesar 0,215 dan tingkat signifikansi dari masing-masing variabel kurang dari 0,05 . Jadi, dapat disimpulkan bahwa masing-masing butir pertanyaan adalah valid.

Hasil Uji Reliabilitas

\begin{tabular}{|l|c|c|}
\hline \multicolumn{1}{|c|}{ Variabel } & Cronbach Alpha & Kriteria \\
\hline Kualitas Produk $\left(\mathrm{X}_{1}\right)$ & 0,706 & Reliabel \\
Persepsi Kualitas Layanan $\left(\mathrm{X}_{2}\right)$ & 0,675 & Reliabel \\
Persepsi Harga $\left(\mathrm{X}_{3}\right)$ & 0,677 & Reliabel \\
Kepuasan Konsumen $(\mathrm{Y})$ & 0,633 & Reliabel \\
\hline
\end{tabular}

Sumber : Data primer diolah dengan SPSS For Windows

Dari tabel di atas, terlihat bahwa nilai Cronbach Alpha dari tiap-tiap konstruk lebih besar dari 0,60 yang berarti bahwa kuesioner yang merupakan indikator - indikator dari variabel atau konstruk tersebut reliabel atau handal.
Analisis Regresi Linear Berganda digunakan untuk mengetahui seberapa besar pengaruh variabel independen terhadap variabel dependen diperoleh hasil:

\section{Coefficientsa}

\begin{tabular}{|c|c|c|c|c|c|c|c|}
\hline \multirow[t]{2}{*}{ Model } & \multicolumn{2}{|c|}{$\begin{array}{l}\text { Unstandardized } \\
\text { Coefficients }\end{array}$} & \multirow{2}{*}{$\begin{array}{c}\begin{array}{l}\text { Standardized } \\
\text { Coefficients }\end{array} \\
\text { Beta } \\
\end{array}$} & \multirow[b]{2}{*}{$\mathrm{t}$} & \multirow[b]{2}{*}{ Sig. } & \multicolumn{2}{|c|}{ Collinearity Statistics } \\
\hline & $\mathrm{B}$ & Std. Error & & & & Tolerance & VIF \\
\hline $1 \quad$ (Constant) & 1.949 & 1.837 & & 1.061 & .292 & & \\
\hline KUALITAS PRODUK & .185 & .071 & .279 & 2.606 & .011 & .819 & 1.222 \\
\hline KUALITAS LAYANAN & .213 & .067 & .311 & 3.199 & .002 & .991 & 1.009 \\
\hline PERSEPSI HARGA & .164 & .105 & .167 & 1.563 & .122 & .817 & 1.224 \\
\hline
\end{tabular}

Sumber : Data primer diolah dengan SPSS For Windows

Berdasarkan Tabel mengenai hasil estimasi Regresi Linear Berganda dengan program SPSS for windows, maka dapat disimpulkan persamaan regresi linear berganda dalam penelitian ini adalah sebagai berikut: $\mathrm{Y}=1.949+0,279 \mathrm{X} 1+0,311 \mathrm{X} 2+0,167 \mathrm{X} 3$ Dimana : $\mathrm{Y}=$ Kepuasan Konsumen $\mathrm{X} 1=$ Kualitas Produk
$\mathrm{X} 2$ = Persepsi Kualitas Layanan

X3 $=$ Persepsi Harga

Uji $t$ pada dasarnya menunjukkan seberapa jauh pengaruh satu variabel independen secara individual dalam menerangkan variasi variabel dependen.

Hasil Linear Berganda (Uji t)

Coefficientsa

\begin{tabular}{|c|c|c|c|c|c|c|c|}
\hline \multirow[b]{2}{*}{ Model } & \multicolumn{2}{|c|}{$\begin{array}{c}\text { Unstandardized } \\
\text { Coefficients }\end{array}$} & \multirow{2}{*}{$\begin{array}{c}\begin{array}{r}\text { Standardized } \\
\text { Coefficients }\end{array} \\
\text { Beta } \\
\end{array}$} & \multirow[b]{2}{*}{$\mathrm{t}$} & \multirow[b]{2}{*}{ Sig. } & \multicolumn{2}{|c|}{ Collinearity Statistics } \\
\hline & B & Std. Error & & & & Tolerance & VIF \\
\hline $\begin{array}{ll}1 & \text { (Constant) }\end{array}$ & 1.949 & 1.837 & & 1.061 & .292 & & \\
\hline KUALITAS PRODUK & .185 & .071 & .279 & 2.606 & .011 & .819 & 1.222 \\
\hline KUALITAS LAYANAN & .213 & .067 & .311 & 3.199 & .002 & .991 & 1.009 \\
\hline PERSEPSI HARGA & .164 & .105 & .167 & 1.563 & .122 & .817 & 1.224 \\
\hline
\end{tabular}

Sumber : Data primer diolah dengan SPSS For Windows

Hasil perhitungan koefisien regresi dengan Uji t adalah sebagai berikut dimana Nilai thitung pada variabel Kualitas Produk $\left(\mathrm{X}_{1}\right)$ adalah sebesar 2,606 dengan tingkat signifikansi 0,11. Karena thitung 2,606 > t tabel 1,989 dengan tingkat signifikansi 0,011<0,05 maka Ho ditolak dan Ha diterima. Kesimpulan :"Kualitas produk berpengaruh positif terhadap kepuasan konsumen" terbukti akan kebenarannya. Atau dengan kata lain variabel kualitas produk 
berpengaruh secara individual dan signifikan terhadap kepuasan konsumen.

Nilai t hitung pada variabel Kualitas Layanan $\left(\mathrm{X}_{2}\right)$ adalah sebesar 3,199 dengan tingkat signifikansi 0,002. Karena thitung 3,199 $>$ t tabel 1,989 dengan tingkat signifikansi 0,002 $<0,05$ maka Ho ditolak dan Ha diterima. Kesimpulan :'Kualitas layanan berpengaruh positif terhadap kepuasan konsumen" terbukti akan kebenarannya. Atau dengan kata lain variabel kualitas layanan berpengaruh secara idividual dan signifikan terhadap kepuasan Konsumen.

Nilai t hitung pada variabel Persepsi Harga $\left(X_{3}\right)$ adalah sebesar 1,563 dengan tingkat signifikansi 0,122. Karena thitung 1,563 $<$ ttabel
1,989 dengan tingkat signifikansi 0,122>0,05 maka Ho diterima dan Ha ditolak. Kesimpulan : “ Persepsi harga berpengaruh positif terhadap kepuasan konsumen" terbukti akan kebenarannya. Atau dengan kata lain variabel persepsi harga berpengaruh secara individual tetapi tidak signifikan terhadap kepuasan konsumen.

Selain itu, dalam penelitian ini juga membuktikan kebenaran hipotesis dengan Uji F pada dasarnya menunjukkan apakah semua variabel independen yang dimasukkan dalam model mempunyai pengaruh secara simultan atau bersama-sama terhadap variabel dependen Hasil Estimasi Linear Berganda (Uji F)

\begin{tabular}{|rl|r|r|r|r|r|}
\hline & & \multicolumn{1}{c}{ Sum of } & & & \\
Model & & Squares & df & Mean Square & F & Sig. \\
\hline 1 & Regression & 80.176 & 3 & 26.725 & 8.653 & $.000^{\mathrm{a}}$ \\
& Residual & 250.177 & 81 & 3.089 & & \\
& Total & 330.353 & 84 & & & \\
\hline
\end{tabular}

a. Predictors:(Constant), PERSEPSI HARGA, KUALITAS LAYANAN, KUALITAS PRODUK

b. Dependent Variable: KEPUASAN KONSUMEN Sumber : Data primer diolah dengan SPSS For Windows

Berdasarkan uji ANOVA atau F test, maka dapat diperoleh Fhitung sebesar 8,653 dengan tingkat signifikansi 0,000 . Oleh karena probabilitas jauh lebih kecil daripada 0,05 (0,000 lebih kecil dari 0,05) dan Fhitung lebih besar dari Ftabel $(8,653$ lebih besar dari 2,71) maka dapat dinyatakan bahwa variabel independen yang meliputi kualitas produk (X1), persepsi kualitas layanan (X2), dan persepsi harga (X3) secara simultan atau bersama-sama mempengaruhi variabel kepuasan konsumen (Y).

Koefisien Determinasi $\left(\mathrm{R}^{2}\right)$ pada intinya mengukur seberapa jauh kemampuan model dalam menerangkan variasi variabel dependen.

Koefisien Determinasi $\left(\mathrm{R}^{2}\right)$

Model Summaryb

\begin{tabular}{|c|c|c|c|c|c|c|c|c|c|c|}
\hline \multirow[b]{2}{*}{ Model } & \multirow[b]{2}{*}{$\mathrm{R}$} & \multirow[b]{2}{*}{ R Square } & \multirow[b]{2}{*}{$\begin{array}{l}\text { Adjusted } \\
\text { R Square }\end{array}$} & \multirow[b]{2}{*}{$\begin{array}{l}\text { Std. Error of } \\
\text { the Estimate }\end{array}$} & \multicolumn{5}{|c|}{ Change Statistics } & \multirow[b]{2}{*}{$\begin{array}{c}\text { Durbin-W } \\
\text { atson }\end{array}$} \\
\hline & & & & & $\begin{array}{l}\text { R Square } \\
\text { Change }\end{array}$ & F Change & dfl & $\mathrm{df2}$ & Sig. F Change & \\
\hline 1 & $.493^{\mathrm{a}}$ & .243 & .215 & 1.75744 & .243 & 8.653 & 3 & 8 & .000 & 1.768 \\
\hline
\end{tabular}

a. Predictors: (Constant), PERSEPSI HARGA, KUALITAS

LAYANAN, KUALITAS PRODUK

b. Dependent Variable: KEPUASAN PELANGGAN

Sumber : Data primer diolah dengan SPSS For Windows
Tampilan output SPSS model Summary besarnya Adjusted $R$ Square adalah 0,243. Hal ini berarti hanya 24,3 persen variasi kepuasan pelanggan (Y) yang dapat dijelaskan oleh variabel-variabel independen yaitu kualitas produk, persepsi kualitas layanan, dan persepsi 
harga. Sedangkan sisanya $(100 \%-24,3 \%=$ $75,7 \%$ ) dijelaskan oleh sebab-sebab lainnya di luar model yang tidak diteliti dalam penelitian ini. Jadi, dapat disimpulkan bahwa masing masing butir pertanyaan adalah valid. Uji Reliabilitas menunjukkan bahwa nilai Cronbach Alpha dari tiap-tiap konstruk atau variabel lebih besar dari 0,60 yang berarti bahwa kuesioner yang merupakan indikatorindikator dari variabel tersebut adalah reliabel atau handal. Hal tersebut dapat dilihat dari hasil pengujian yang telah dilakukan sebagai berikut : variabel Kualitas Produk (X1) nilai Cronbach Alpha-nya sebesar 0,7061, Persepsi Kualitas Layanan (X2) sebesar 0,6756, Persepsi Harga (X3) sebesar 0,6779, dan Kepuasan Konsumen (Y) sebesar 0,6336. Dari hasil estimasi Regresi Linear Berganda dengan program SPSS for windows maka persamaan regresi linear berganda dalam penelitian ini adalah sebagai berikut :

$\mathrm{Y}=1.949+0,279 \mathrm{X} 1+0,311 \mathrm{X} 2+0,167 \mathrm{X} 3$

Dimana :

$\mathrm{Y}=$ Kepuasan Konsumen

$\mathrm{X} 2=$ Kualitas Layanan

$\mathrm{X} 1=$ Kualitas Produk

X3 = Persepsi Harga

Model tersebut berarti bahwa setiap terjadi kenaikan Kualitas Produk (X1) akan diikuti kenaikan Kepuasan Konsumen (Y) apabila variabel lain yang mempengaruhi dalam keadaan Ceteris Paribus. Kemudian setiap terjadi kenaikan Kualitas Layanan (X2) akan diikuti kenaikan Kepuasan Konsumen (Y) apabila variabel lain yang mempengaruhi dalam keadaan Ceteris Paribus dan setiap terjadi kenaikan Persepsi Harga (X3) akan diikuti kenaikan Kepuasan Konsumen (Y) apabila variabel lain yang mempengaruhi dalam keadaan Ceteris Paribus. Berdasarkan garis regresi yang dihasilkan maka dapat dilihat bahwa dari tiga variabel yang digunakan dalam penelitian ini yang memiliki pengaruh paling besar terhadap kepuasan konsumen adalah kualitas layanan yaitu sebesar 0,311 sedangkan kualitas produk hanya memiliki pengaruh sebesar 0,279 dan persepsi harga memiliki pengaruh 0,167 . Hasil pengujian
Goodness of Fit antara lain : hasil dari Uji t menunjukkan bahwa semua variabel independen, yakni kualitas produk, kualitas layanan, dan persepsi harga mempunyai signifikansi kurang dari 0,05. Untuk hasil perhitungan didapat thitung masingmasing variabel sebesar 2,605 untuk Kualitas Produk (X1), 3,199 untuk Kualitas Layanan (X2), dan 1,563 untuk Persepsi Harga (X3). Dimana hasil perhitungan masing-masing variabel lebih besar dari t tabel -nya yaitu sebesar 1,989. Dari variabel-variabel independent pada penelitian ini, pengaruh yang dominan terhadap variabel dependen adalah kualitas layanan, ini berarti variabel X2 yang paling penting dalam menentukan kepuasan konsumen Air Minum Dalam Kemasan CV. Sentosa Abadi di Kabupaten Sekadau.

\section{KESIMPULAN DAN SARAN}

Berdasarkan penelitian tentang pengaruh kualitas produk, kualitas layanan, dan persepsi harga terhadap kepuasan Konsumen Air Minum Dalam Kemasan CV. Sentosa Abadi di Kabupaten Sekadau sebagai berikut: Terdapat pengaruh positif dan signifikan kualitas produk terhadap kepuasan konsumen hal tersebut dibuktikan dengan Uji $\mathrm{t}$ adalah sebagai berikut dimana Nilai t hitung pada variabel Kualitas Produk $\left(\mathrm{X}_{1}\right)$ adalah sebesar 2,606 dengan tingkat signifikansi 0,11 . Karena thitung 2,606 $>\mathrm{t}$ tabel 1,989 dengan tingkat signifikansi $0,011<0,05$ maka Ho ditolak dan Ha diterima. Terdapat pengaruh positif dan signifikan kualitas layanan terhadap kepuasan konsumen hal tersebut dibuktikan dengan Uji t hitung pada variabel Kualitas Layanan $\left(\mathrm{X}_{2}\right)$ adalah sebesar 3,199 dengan tingkat signifikansi 0,002. Karena thitung 3,199> $\mathrm{t}$ tabel 1,989 dengan tingkat signifikansi 0,002< 0,05 maka Ho ditolak dan Ha diterima. Tidak Terdapat pengaruh positif dan signifikan persepsi harga terhadap kepuasan konsumen hal tersebut dibuktikan dengan Uji t hitung pada variabel Persepsi Harga $\left(\mathrm{X}_{3}\right)$ adalah sebesar 1,563 dengan tingkat signifikansi 0,122 . Karena thitung $1,563<$ ttabel 1,989 dengan tingkat signifikansi 0,122> 0,05 maka Ho diterima dan Ha ditolak. Terdapat 
pengaruh positif dan signifikan pengaruh kualitas produk, kualitas layanan, persepsi harga terhadap kepuasan konsumen ini dibuktikan uji ANOVA atau $\mathrm{F}$ test, maka dapat diperoleh Fhitung sebesar 8,653 dengan tingkat signifikansi 0,000 . Oleh karena probabilitas jauh lebih kecil daripada 0,05 $(0,000$ lebih kecil dari 0,05) dan Fhitung lebih besar dari Ftabel $(8,653$ lebih besar dari 2,71) maka dapat dinyatakan bahwa variabel independen yang meliputi kualitas produk (X1), persepsi kualitas layanan (X2), dan persepsi harga (X3) secara simultan atau bersama-sama mempengaruhi variabel kepuasan konsumen $(\mathrm{Y})$. Selanjutnya dibuktikan lagi dengan Tampilan output SPSS model Summary besarnya Adjusted $R$ Square adalah 0,243. Hal ini berarti hanya 24,3 persen variasi kepuasan pelanggan (Y) yang dapat dijelaskan oleh variabel-variabel independen yaitu kualitas produk, persepsi kualitas layanan, dan persepsi harga. Sedangkan sisanya $(100 \%-24,3 \%=75,7 \%)$ dijelaskan oleh

\section{DAFTAR PUSTAKA}

Arikunto, 2002., Produser penelitian suatu pendekatan praktek, Rineka Cipta, Jakarta.

Bolton dan Drew, 1991. A Multistage Model of Customers' Assessments of Service Quality and Value

Bungin, 2005. Metodologi Penelitian Kuantitatif Komunikasi, Ekonomi, dan Kebijakan Publik serta Ilmu-Ilmu Sosial Lainnya, Edisi Pertama, Cetakan Pertama, Jakarta.:Prenada Media.

Gronroos (1994), From Marketing Mix To Relationship Marketing to Relationship, toward a Paradigma Shift in Marketing.

Husein, 2002. Riset Pemasaran dan Perilaku

Konsumen. Jakarta: PT. Gramedia Pustaka Utama

Kenna, 1991. The Essence of Manajemen Sumber Daya Manusia, Edisi Pertama, Yogyakarta: ANDI

Kotler dan Amstrong, 1997. rinsip Pemasaran.2001.Jakarta; Erlangga

Kotler, 2002. Manajemen Pemasaran.. Jakarta : Indeks. sebab-sebab lainnya di luar model yang tidak diteliti dalam penelitian ini.

Berdasarkan kesimpulan tentang pengaruh kualitas produk, kualitas layanan, dan persepsi harga terhadap kepuasan Konsumen Air Minum Dalam Kemasan CV. Sentosa Abadi di Kabupaten Sekadau, maka disarankan sebagai berikut: 1 . Sebaiknya Air Minum Dalam Kemasan CV. Sentosa Abadi di Kabupaten Sekadau untuk meningkatkan kepuasan konsumen meningkatkan kualitas produk dengan berbagai tampilan yang menarik. 2 Sebaiknya Air Minum Dalam Kemasan CV. Sentosa Abadi di Kabupaten Sekadau untuk meningkatkan kepuasan konsumen meningkatkan Persepsi Kualitas Layanan dengan cepat dan reponsif. 3. Sebaiknya Air Minum Dalam Kemasan CV. Sentosa Abadi di Kabupaten Sekadau untuk meningkatkan kepuasan konsumen menuntukan harga jual terendah yang dapat terjangkau oleh konsumen dan masih menguntungkan pihak perusahaan.

Mowen, 1995. Perilaku Konsumen dan Komunikasi Pemasaran, Jakarta: karangan Sutisna.

Oliver (1997). Membangun Kepuasan Pelanggan. Jakarta: Gramedia Pustaka Utama

Parasuraman, et.al (1991 Playanan Pelanggan yang Sempurna.Yogyakarta: Kunci Ilmu,

Parasuraman, Zeithami dan Berry, 1985. A Conceptual Model of Service Quality and Its Implication for Future Research," Journal of Marketing,

Stanton, 2004. Prinsip Pemasaran.1984.Jakarta;Erlangga

Swastha, 2000. Pengantar Bisnis Modern, Pengantar Ekonomi Perusahaan. Modern, Jakarta : Liberty.

Tjiptono, 1996. Total Service Quality, Yogyakarta: Andi Offset.

Tse dan Wilton, 1988. Models of Consumer Satisfaction Formation: nExtention"

Wilkie, 1990. Wilkie, L. William, Consumer Behavior, Edisi Ketiga,

Zeithaml dan Bitner, 1996. Services Marketing: Integrating Customer Focus Across The Firm, Second Edition Hill. . New York: McGraw 